\title{
BEHAVIOUR OF A SPACE INVERTED TRIANGULAR STEEL TRUSS
}

\section{ANDREJS PODKORITOVS ${ }^{1}$, DMITRIJS SERDJUKS ${ }^{2}$, VADIMS GOREMIKINS ${ }^{3^{*}}$, KARINA BUKA-VAIVADE ${ }^{4}$, MIKHAIL NIKOLAEVICH KIRSANOV ${ }^{5}$ \\ ${ }^{1-4}$ Department of Structural Engineering, Riga Technical University, Riga, Latvia \\ ${ }^{5}$ Department of Robotics, Mechatronics, Dynamics and Strength of Machines, National Research University "Moscow Power Engineering Institute" (MPEI), Moscow, Russian Federation}

Received 10 September 2019; accepted 8 February 2020

\begin{abstract}
Behaviour of the inverted triangular truss, which is widely used as a bridge girder, was investigated analytically and experimentally. Cold-formed square hollow cross-sections of steel grade S355J2H with dimensions $80 \mathrm{~mm} \times$ $4 \mathrm{~mm}, 90 \mathrm{~mm} \times 4 \mathrm{~mm}$ and $40 \mathrm{~mm} \times 4 \mathrm{~mm}$ were selected for the top and bottom chords and bracing elements of the truss with $12.56 \mathrm{~m}$ span, correspondingly. Five FEM models were developed using software Dlubal RFEM. The main specific feature of the models is the difference in modelling of joint behaviour
\end{abstract}

* Corresponding author. E-mail: vadims.goremikins@rtu.lv

Dmitrijs SERDJUKS (ORCID ID 0000-0002-1843-3061)

Vadims GOREMIKINS (ORCID ID 0000-0002-7191-3128)

Karina BUKA-VAIVADE (ORCID ID 0000-0001-7296-8158)

Mikhail Nikolaevich KIRSANOV (ORCID ID 0000-0002-8588-3871)

Copyright (C) 2020 The Author(s). Published by RTU Press

This is an Open Access article distributed under the terms of the Creative Commons Attribution License (http://creativecommons.org/licenses/by/4.0/), which permits unrestricted use,

distribution, and reproduction in any medium, provided the original author and source are credited. 
considering plastic behaviour and stiffness of truss connections. It was shown that the FE model of the truss where the members were modelled by the truss type finite elements and the joints modelled by the shell type ones allows predicting behaviour of the truss with precision of up to $3.9 \%$. It was shown that precision of the suggested FEM model grows 4.36 to 4.62 times in comparison with the traditional FEM models where the members were modelled by the truss finite elements with the pinned and rigid joints in case of plastic joint behaviour. Precision of the suggested FEM model is identical to that of the traditional FEM models regarding the case of elastic joint behaviour.

Keywords: FEM models, joint modelling, plastic work, square hollow sections, static loading, triangular steel truss, vertical displacements.

\section{Introduction}

Triangular steel trusses with hollow sections are widely used in bridge and roof structures as truss girders due to their increased spatial stability and decreased material consumption in comparison with the planar trusses (Durfee, 1987; Gao, Bai, Jiang, Wang \& HE, 2018). Triangular trusses with hollow cross-sections are also used for crane booms and transmission towers (Durfee, 1986). Bridges with triangular trusses are characterized by decreased material consumption and corresponding dead weight compared with the rectangular truss bridges (Belevičius, Juozapaitis, Rusakevičius, Misiūnaitė \& Valentinavičius, 2017). Inverted triangular trusses cause special interest due to their wide range of application in the composite and movable bridges (Blandford, 1996; Dauner, Oribasi \& Wery, 1998; Reis \& Oliveira Pedro,
Andrejs Podkoritovs, Dmitrijs Serdjuks, Vadims Goremikins, Karina Buka-Vaivade, Mikhail Nikolaevich Kirsanov

Behaviour of a Space Inverted Triangular Steel Truss
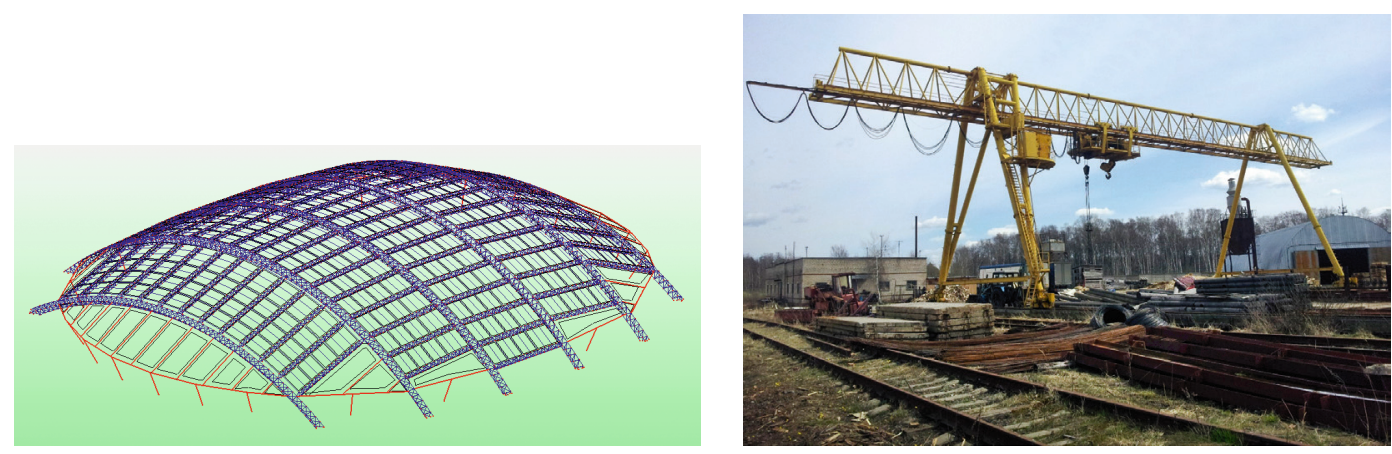

Figure 1. Use of inverted triangular trusses in roof and crane structures:

a) roof with the curved inverted triangular trusses (Gusevs, Serdjuks, Artebjakina, Afanasjeva \& Goremikins, 2016); b) crane structure with a triangular truss 
2011; Zhang, Zhao, Li \& Huang, 2017). Uses of inverted triangular trusses in roof and crane structures are shown in Figure 1.

The structure of the velodrome roof is shown in Figure 1a. The major load-bearing structures of the roof are presented by six curved inverted triangular trusses placed with the bay of $20 \mathrm{~m}$ and additional purlins, inverted triangular trusses, placed with the bay of $2 \mathrm{~m}$. Members of the chords and lattice have hollow cross-sections (European Committee for Standardization, 2005). The inverted triangular truss with hollow crosssections is considered an object of investigation in the current study (Figure 2).

Safe exploitation of steel structural members requires evaluation of their experimental load-carrying capacity (Paeglite, Smirnovs, \& Paeglitis, 2018). A range of plastic behaviours of connections and cross-sections that the considered structure may demonstrate can be determined in this case. The experimental load-carrying capacity can be used for control of general analysis results, specifically in cases, when load-carrying capacity of the structure should be evaluated analytically. Deformation values and corresponding deflections related to the experimental load-carrying capacity of the structure can be used for structural monitoring, which allows determining the critical level of the load when plastic deformations get irreversible and become uncontrollable. The load can achieve its critical value in case of emergency, which can occur for several reasons, such as error in design, overloading during assembly due to unfavourable placement of materials or during operation, and various accidents. The available values of plastic deformation of structural members and joints related to the experimental load-carrying capacity of the structure can be found only experimentally. However, theoretical determination of the available plastic deformation values of the steel structures is currently a topical issue (European Committee for Standardization, 2005). Therefore, the current investigation aims at the development of analytical models that would allow predicting behaviour of the

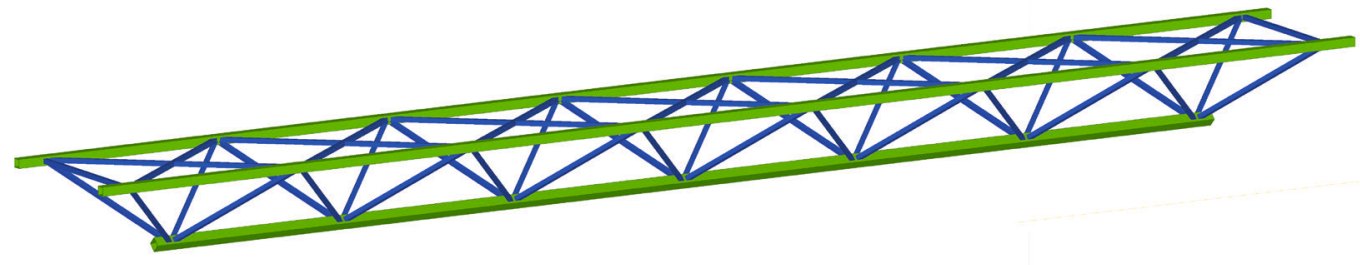

Figure 2. Inverted triangular truss with hollow cross-sections (Podkoritovs, 2018) 
inverted triangular steel truss with hollow cross-sections taking into account plastic deformations. The developed analytical models should be validated by experiment.

\section{Description of the object of investigation}

The inverted triangular truss with the length of $12.56 \mathrm{~m}$ was considered as an object of investigation. The height and width of the truss are $0.8 \mathrm{~m}$ and $1.48 \mathrm{~m}$, respectively. The distance between the nodes of the top and bottom chords is equal to $1.713 \mathrm{~m}$ (Figure 3). The steel of grade $\mathrm{S} 355 \mathrm{~J} 2 \mathrm{H}$ was chosen as the structural material.

The cold-formed square hollow cross-sections with dimensions of $80 \mathrm{~mm} \times 4 \mathrm{~mm}, 90 \mathrm{~mm} \times 4 \mathrm{~mm}$ and $40 \mathrm{~mm} \times 4 \mathrm{~mm}$ were selected for the top and bottom chords and members of the lattice, correspondingly. The dimensions of cross-sections were selected to ensure that the relation between the widths of the lattice members and the chords is less than 0.85 . It is necessary to provide the maximum influence of the joint stiffnesses on the vertical displacements of the truss (Podkoritovs, 2018).
Andrejs Podkoritovs, Dmitrijs Serdjuks, Vadims Goremikins, Karina Buka-Vaivade, Mikhail Nikolaevich Kirsanov

Behaviour of a Space Inverted Triangular Steel Truss

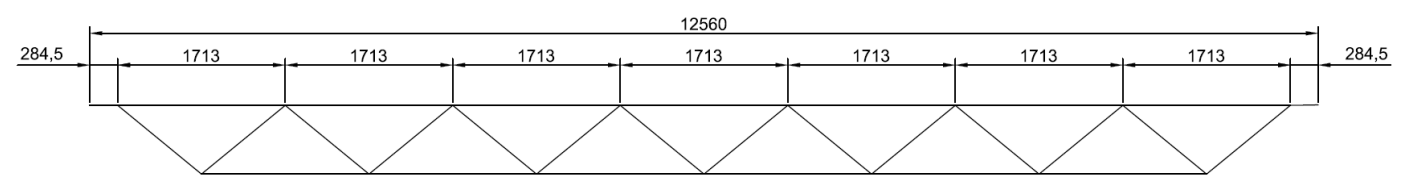

a)

b)

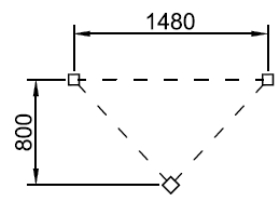

c)

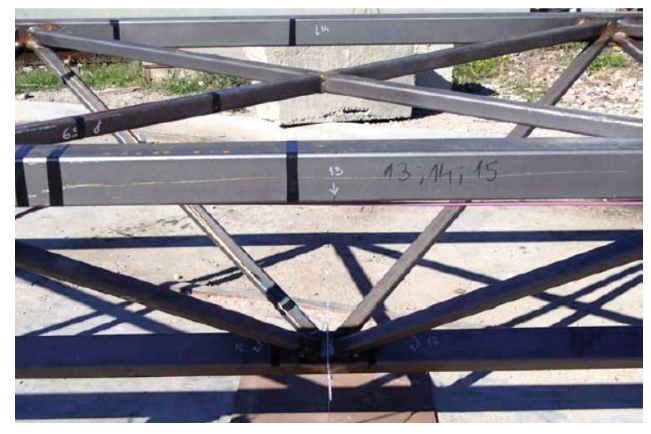

Figure 3. a) geometric scheme of the considered inverted triangular truss with hollow cross-sections; b) cross-section of the truss;

c) scheme of the lattice in plane of the top chord and the joint of the lattice members with the bottom chord (Podkoritovs, 2018) 


\section{Development of FEM models of inverted hollow section triangular truss}

\subsection{Short description of the existing approaches to truss modelling}

Existing approaches to design of the planar and spacious steel trusses are based on the elastic behaviour of structural members and connections. Additional bending moments are taken into account in design of the chords and bracing members depending on the values of eccentricities, which took place in the joints and corresponding intensities of the bending moments (Misiūnaitè, Rimkus, Jakuboskis, Sokolov \& Gribniak, 2019). The recommended truss models should be characterized by the pin joints to ensure good correspondence between analytical and experimental results in case the joints and members of the trusses behave elastically. The trusses are modelled by the finite element method realized by different software, using continuous chords and pinned connections of bracings and chords (Kirsanov \& Zaborskaya, 2017). The connection of the chord and a bracing member can be modelled by extremely stiff member, which allows developing the overlap and gap joints in cases of negative and positive eccentricities, respectively (Figure 4).

The bending moments, which took place due to rigid joint of the bracing members and chords, can be neglected in most cases owing to sufficient deformability of the chord web and possibility of rotation of the members in the joints.

The values of vertical displacements obtained by analyzing the trusses with the overlap joints will be higher than the real values in case the truss is modelled by continuous chords and pin connection of

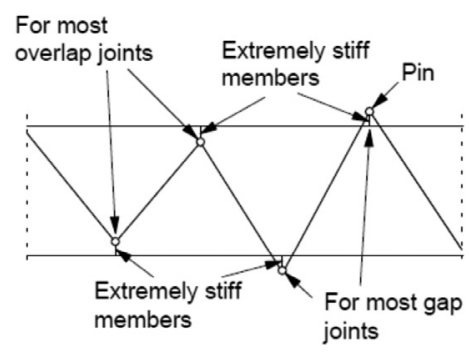

Figure 4. Modelling of the connection between the chord and bracing members of the truss (Podkoritovs, 2018) 
bracing and chord (Coutie \& Saidani, 1991; Podkoritovs, 2018). However, the values of vertical displacements obtained by analyzing the trusses with the gap joints will not exceed their real values (Coutie \& Saidani, 1991; Czechowski, Gasparski, Zycinski, \& Brodka, 1984; Mohamad, Isaev \& Vatin, 2016; Philiastides, 1988; Podkoritovs, 2018). The real values of vertical displacements will be higher than their analytical values due to the slenderness of the chords in place of the gap. For the trusses with rectangular hollow sections, the difference can exceed 12-15\%. Therefore, it is recommended to multiply analytical values of the vertical displacements by the factor equal to 1.15 (Coutie \& Saidani, 1991; Mohamad, Isaev \& Vatin, 2016; Philiastides, 1988; Podkoritovs, 2018).

\subsection{FEM models of the inverted triangular truss with hollow sections}

Five FEM models were developed using the finite element method which was realized using software Dlubal RFEM. All five models have the same view, which is shown in Figure 5. All members of the truss were modelled by the truss type finite element. The elastic-plastic material model was used for the members of the truss.

The differences between the models lie in the modelling of joints. The main specific feature of the models is the difference in modelling of joint behaviour considering plastic behaviour and stiffness of truss connections. Five models of the inverted triangular truss with hollow cross-sections were developed for the purpose. The first model is the classic truss system design model with continuous chords and pinned joints of the members (Frater \& Packer, 1992). The CIDECT Design Guide (Packer, Wardenier, Zhao, Vegte \& Kurobane, 2009) recommends such approach to the modelling of trusses. The first model is characterized by good correlation of the axial forces and bending moments with their real

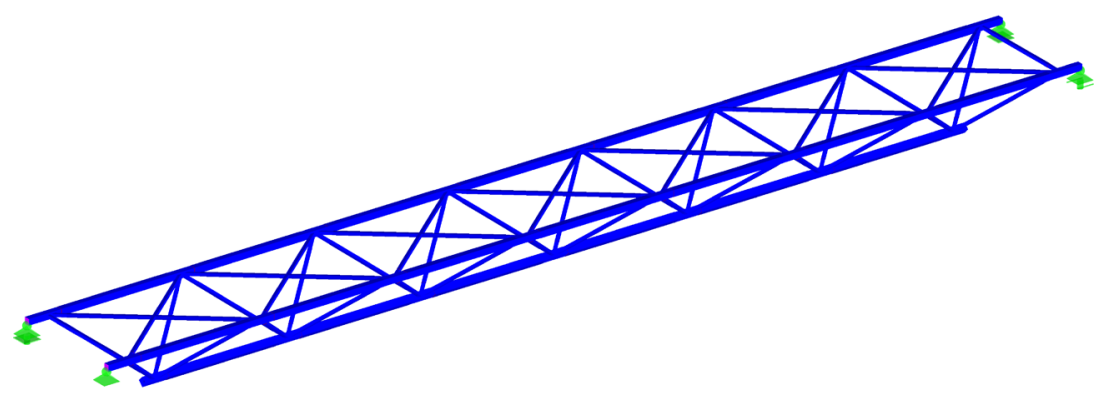

Figure 5. Scheme of the inverted hollow section triangular truss (Podkoritovs, 2018)
Andrejs Podkoritovs, 
values (Mohamad, Isaev \& Vatin, 2016). The truss with the rigid joints of chords and lattice members presents the second model. The second model is characterized by the maximum stiffness and minimum vertical displacements (Liu \& Li, 2013). The second model allows evaluating the values of bending moments and is characterized by the decreased values of the axial forces acting in the members in comparison with the first model with pinned joints of the members. Numerical values of the joint stiffnesses were determined manually using Eqs. (1) to (3).

$$
C_{j, \text { ini }}=\frac{E}{1 / k_{a}},
$$

where $C_{j, i n i}$ - the theoretical stiffness of the joint; $E$ - modulus of elasticity of the joint material; $k_{a}$ - factor, which is determined by Eq. (2).

$$
k_{a}=\frac{N}{v(A) E}=\frac{4 l_{\text {eff }} t_{0}^{3}}{\left(L-b_{1}\right)^{3}},
$$

where $L$ - effective width of the top flange of the chord; $l_{\text {eff }}$ - effective length of the top chord; $b_{1}$ - width of the lattice member; $t_{0}$ - thickness of the cross-section of the chords.

$$
l_{\text {eff }}=h_{1}(2-\beta)+1.25 b_{0}(1-\beta),
$$

where $h_{1}$ - depth of the lattice member; $b_{0}$ - width of the chord member; $\beta$ - relation between the widths of the lattice and chord members.

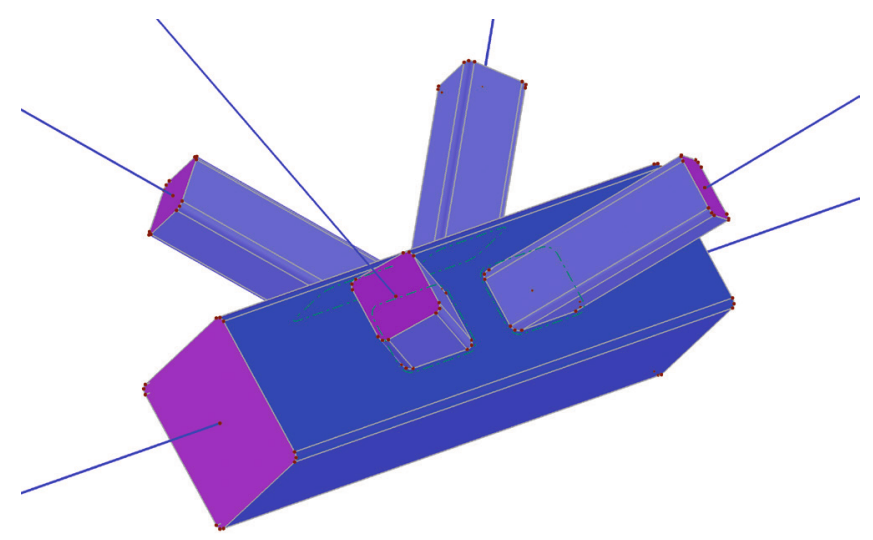

Figure 6. Joint of the bottom chord and bracings of the truss with the lattice members, which is modelled by the shell type finite elements (Podkoritovs, 2018) 
The third and the fourth models were developed taking into account deformability of rigid joints that is proportional to their stiffness. Evaluation of deformability of the rigid joints allows evaluating the influence on the vertical displacements of the truss (Mohamad, Isaev \& Vatin, 2016). The joints of the members in the third and fourth models were considered as a semi-rigid, but deformations of the joints, which are proportional to their stiffnesses, were determined separately by component-based finite element method software IDEA Statica 10. The fifth model was developed using the truss type finite elements for modelling of the members and shell type finite elements for modelling of the joints (Podkoritovs, 2018).

The joint of the bottom chord of the truss with the lattice members, which is modelled by the shell type finite elements, is shown in Figure 6. The shell type finite elements possess six degrees of freedom in each node: three linear displacements and three rotations. The joints with the shell type finite elements are integrated to the model of the structure modelled by the truss type finite elements. (Podkoritovs, 2018).

\section{Testing of the inverted triangular truss}

The inverted hollow section triangular truss discussed in Chapter 2 was statically loaded by seventeen concrete blocks with the dead weight of $1.37 \mathrm{t}$ and dimensions of $2400 \mathrm{~mm} \times 400 \mathrm{~mm} \times 600 \mathrm{~mm}$. Seven loading schemes were realized. Five schemes of block placement are shown in Figure 7.

Schemes 6 and 7 are different from Scheme 5, which is shown in Figure $7 \mathrm{e}$ in that they make use of one and two additional blocks, correspondingly. The truss was loaded using the travelling bridge crane with approximate speed of one block per three minutes. It was predicted that the plastic behaviour of the joints of the tested truss would occur after application of thirteen blocks.

Deflectometer Micro-Epsilon WDS P96 $2500 \mathrm{~mm}$ was used for the measurement of deflection in the middle of the span. The deflectometer was connected to the point of the bottom chord in the middle of the span with a steel wire with diameter of $1 \mathrm{~mm}$ (Figure 8). Twenty strain gauges HBM YL11 6/350 were connected to the surface of the members with glue HBM Z70 and were used for the measurement of strains of the members in the joints of the truss and chords. The scheme of strain gauge placement is shown in Figure 9.

Strain gauges 1, 2, 3, 4 and 5 were first placed on the support joint of the bracings and the bottom chord. Strain gauges 6, 11, 15, 19 and 20
Andrejs Podkoritovs, 


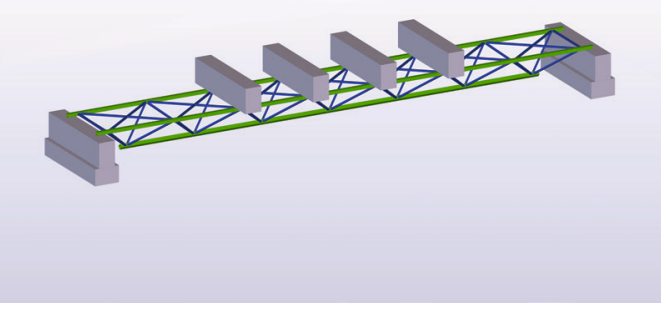

a)

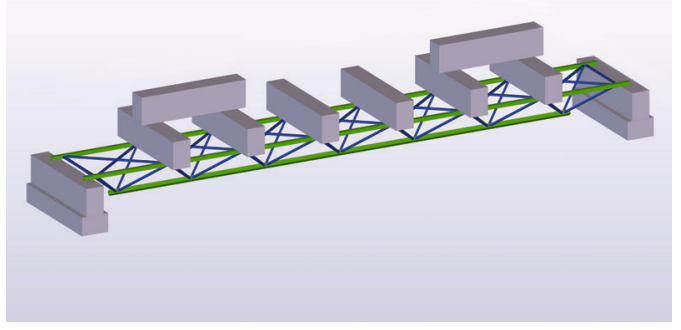

c)

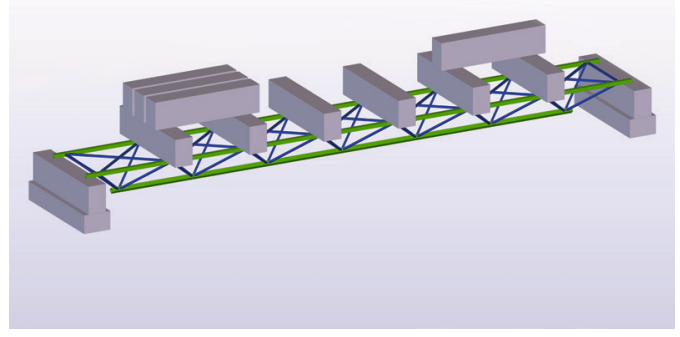

e)

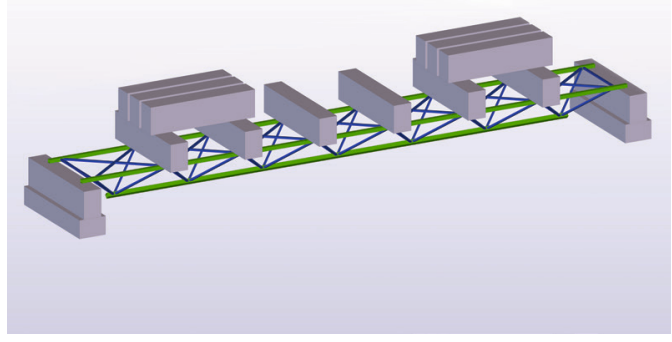

b)

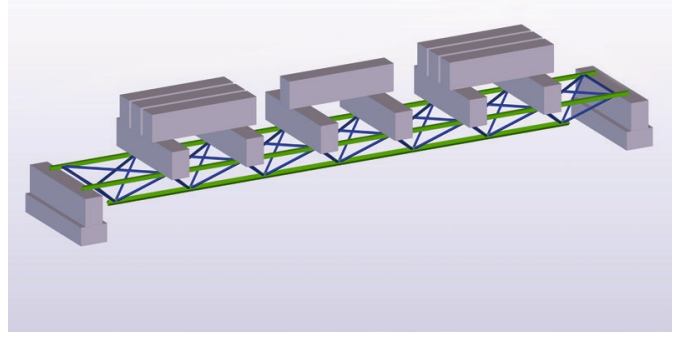

d)

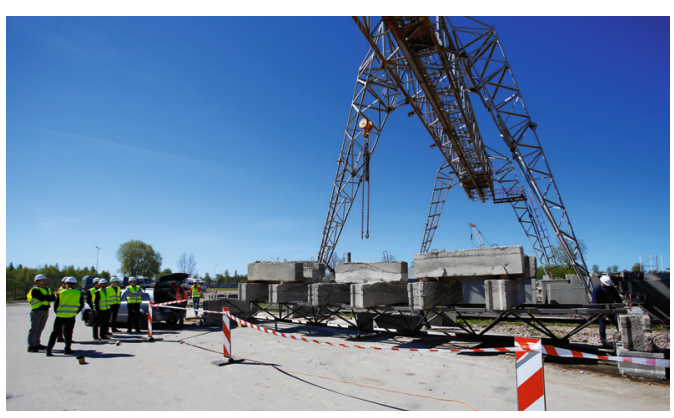

Figure 7. Five loading schemes of the inverted hollow section triangular truss: a) Loading scheme 1 ; b) Loading scheme 2; c) Loading scheme 3; d) Loading scheme 4; e) Loading scheme 5 (Podkoritovs, 2018)

were placed on the bracings joining the left and right parts of the top chord. Strain gauges 7, 8, 9, 10, 12, 18 and 19 were placed on the support joints of the top chord of the truss.

Strain gauges 13, 14 and 16, 17 were placed in the middle of the span on the top and bottom chords of the truss, correspondingly. 
a)

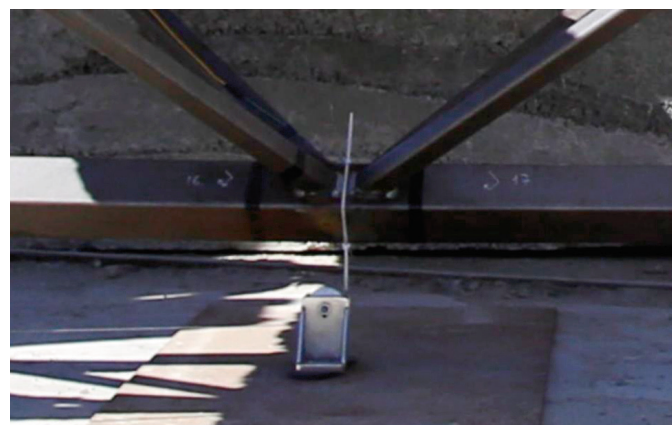

b)

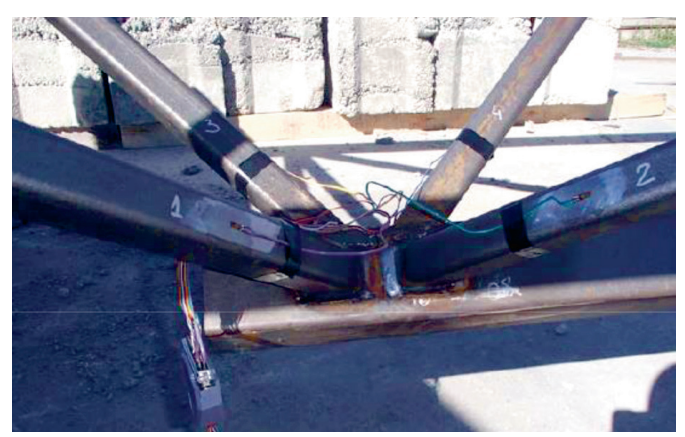

Figure 8. Placement of measuring instruments during the testing of the inverted triangular truss with hollow sections: a) placement of deflectometer Micro-Epsilon WDS P96 $2500 \mathrm{~mm}$ in the middle of the span; b) placement of strain gauges HBM YL11 6/350 on the members in the joint of the truss (Podkoritovs, 2018)

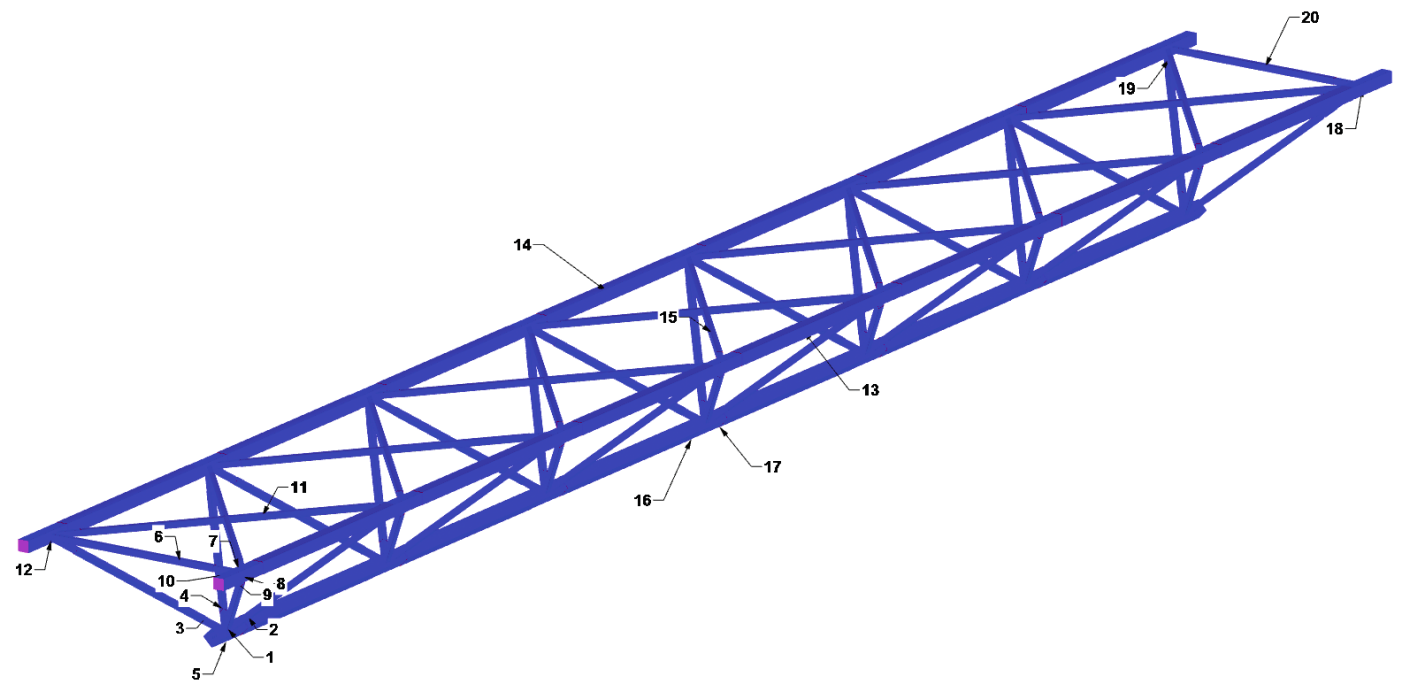

Figure 9. Scheme of placement of strain gauges (Podkoritovs, 2018) 


\section{Analysis of behaviour of the inverted space triangular steel truss}

\subsection{Results of static testing of the inverted hollow section triangular truss}

After application of thirteen blocks, plastic deformations of the truss and corresponding vertical displacements started to grow nonlinearly and after application of seventeen blocks, the process of unloading started. A dependence of displacement on load is shown in Figure 10.

The plastic deformations of the joints and members of the truss, which are growing in time, describe the gap between the charts of loading and unloading processes. The shape of the obtained dependence enables to conclude that plastic deformations of the joints and members of the truss started after application of eleven blocks.

Strains of the members in the joints of the truss were measured by twenty strain gauges. The dependences of the strains on the number of the applied blocks are shown in Figure 11 for strain gauges 1-20.

It can be stated that development of plastic deformations started from the tensioned bottom chord in the middle of the span, where strain gauges 16 and 17 were placed. Plastic deformations started after application of twelve blocks and developed till the application of seventeen blocks. The failure of the truss was not supposed. Residual deformations measured by strain gauges 16 and 17 were equal to $2419 \mu \mathrm{m} / \mathrm{m}$ and $2671 \mu \mathrm{m} / \mathrm{m}$ or

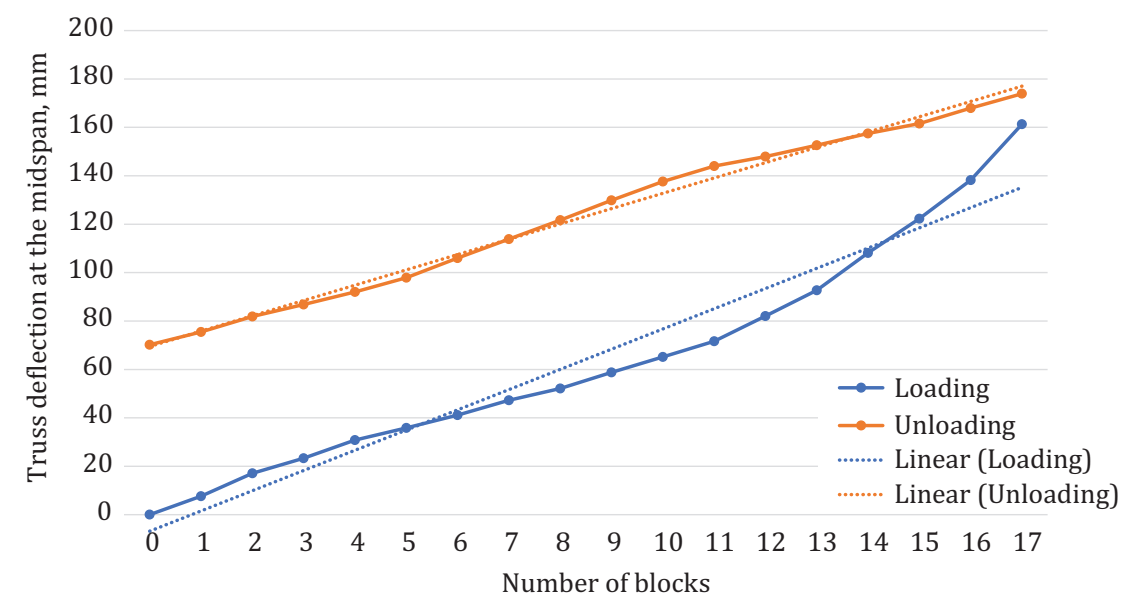

Figure 10. The maximum vertical displacements as a function of the number of blocks 
1500

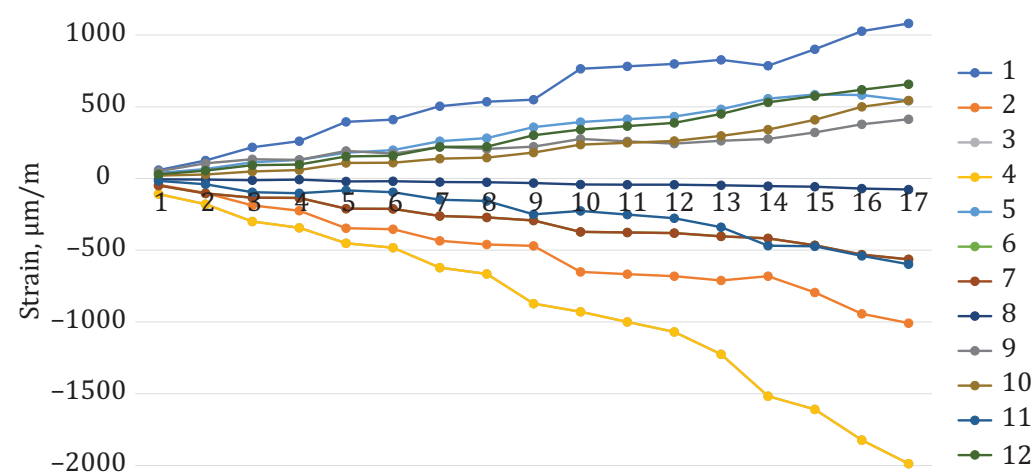

$-2500$

a)

6000

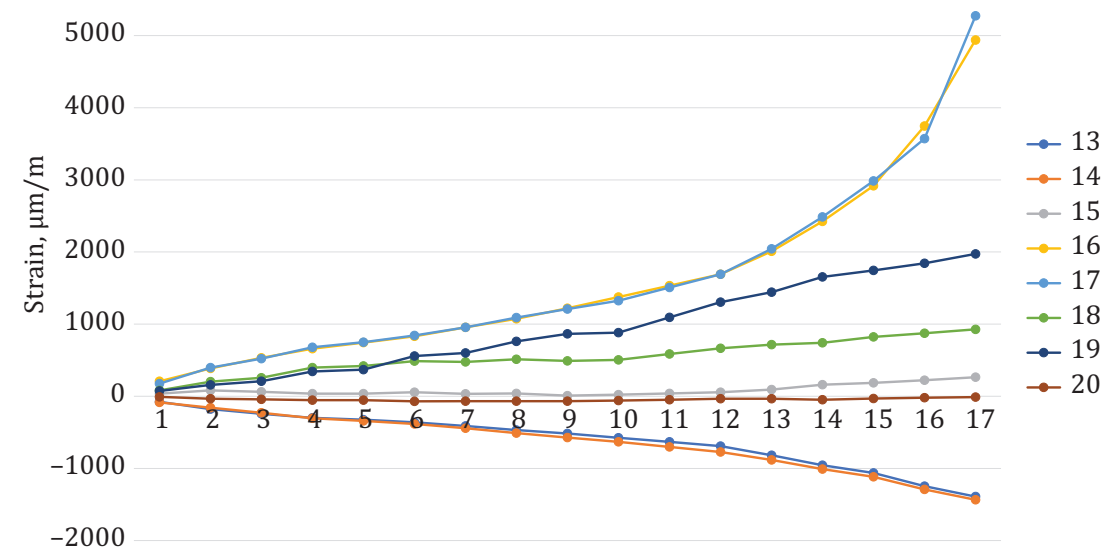

b)

Number of blocks

\section{Number of blocks}

Andrejs Podkoritovs, Dmitrijs Serdjuks,

Vadims Goremikins,

Karina Buka-Vaivade, Mikhail Nikolaevich

Kirsanov

Behaviour of a Space Inverted Triangular

Steel Truss

Figure 11. Strains of the members in the joints of the truss as a function of the number of blocks: a) dependences obtained for strain gauges 1-12; b) dependences obtained for strain gauges 13-20 (Podkoritovs, 2018)

$0.2419 \%$ and $0.2671 \%$, respectively. The maximum vertical displacement, which corresponds to the residual deformations, was equal to $70.2 \mathrm{~mm}$. The results obtained during the loading of the inverted space triangular steel truss were used for verification of the developed five FEM models of the truss (Podkoritovs, 2018). 


\subsection{Verification of FEM models of the inverted triangular truss with hollow sections}

Maximum vertical displacements obtained during the loading of the inverted space triangular steel truss were used for verification of the developed five FEM models of the truss. The maximum vertical displacements obtained by the FEM analysis of the inverted triangular truss were compared with the results obtained in the course of experiment during realization of Loading scheme 4, which is shown in Figure 7d.

The first FEM model with the pinned joints shows good correlation between the analytically and experimentally obtained maximum vertical displacements when the members and joints of the truss were in the elastic stage. The difference in displacements did not exceed 3\% when the truss was loaded using Scheme 1 (Figure 7a). Nevertheless, in the course of realization of Loading scheme 4 , when plastic stage occurred for the members and joints of the truss, the difference between the analytically and experimentally obtained results exceeded $17 \%$. The obtained maximum vertical displacements were predicted by analogous experiments described in the literature (Coutie \& Saidani, 1991; Philiastides, 1988).

The maximum vertical displacements obtained applying the second FEM model with the rigid joint are close to the results obtained using the first one. The difference did not exceed $1 \%$ when the truss was loaded using Scheme 1. The difference grew up to $9.4 \%$ when Loading scheme 2 was realized. However, in the course of realization of Loading scheme 4, when plastic stage occurred for the members and joints of the truss, the

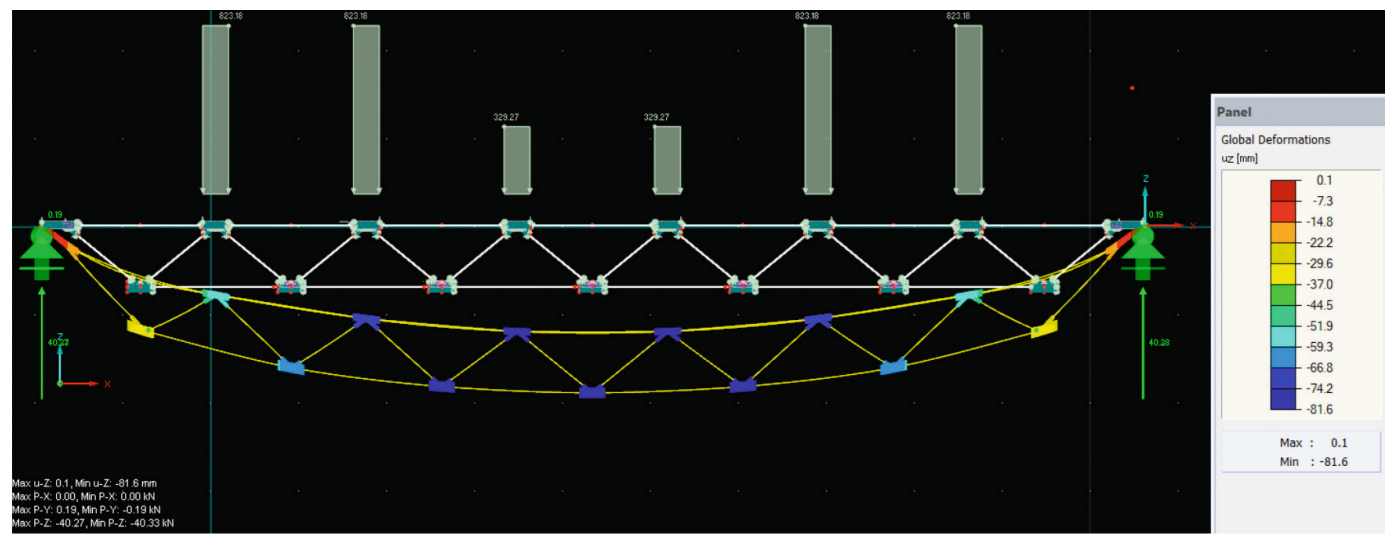

Figure 12. The deformed scheme of the SHS inverted triangular truss (Podkoritovs, 2018) 
difference between the analytically and experimentally obtained results exceeded 18\%. Therefore, it can be concluded that the first and second FEM models of the inverted triangular truss allow predicting correctly the behaviour of the truss in case its members and joints are in the elastic stage.

The results obtained using the third and fourth FEM models with the semi-rigid joints significantly differed from the results obtained using the first and second ones. The differences between the analytically and experimentally obtained results when the structure was loaded using Scheme 1 are comparable with the results obtained using the first and second models and did not exceed 2\%. The difference between the experimentally and theoretically obtained results grew not so quickly as

a)
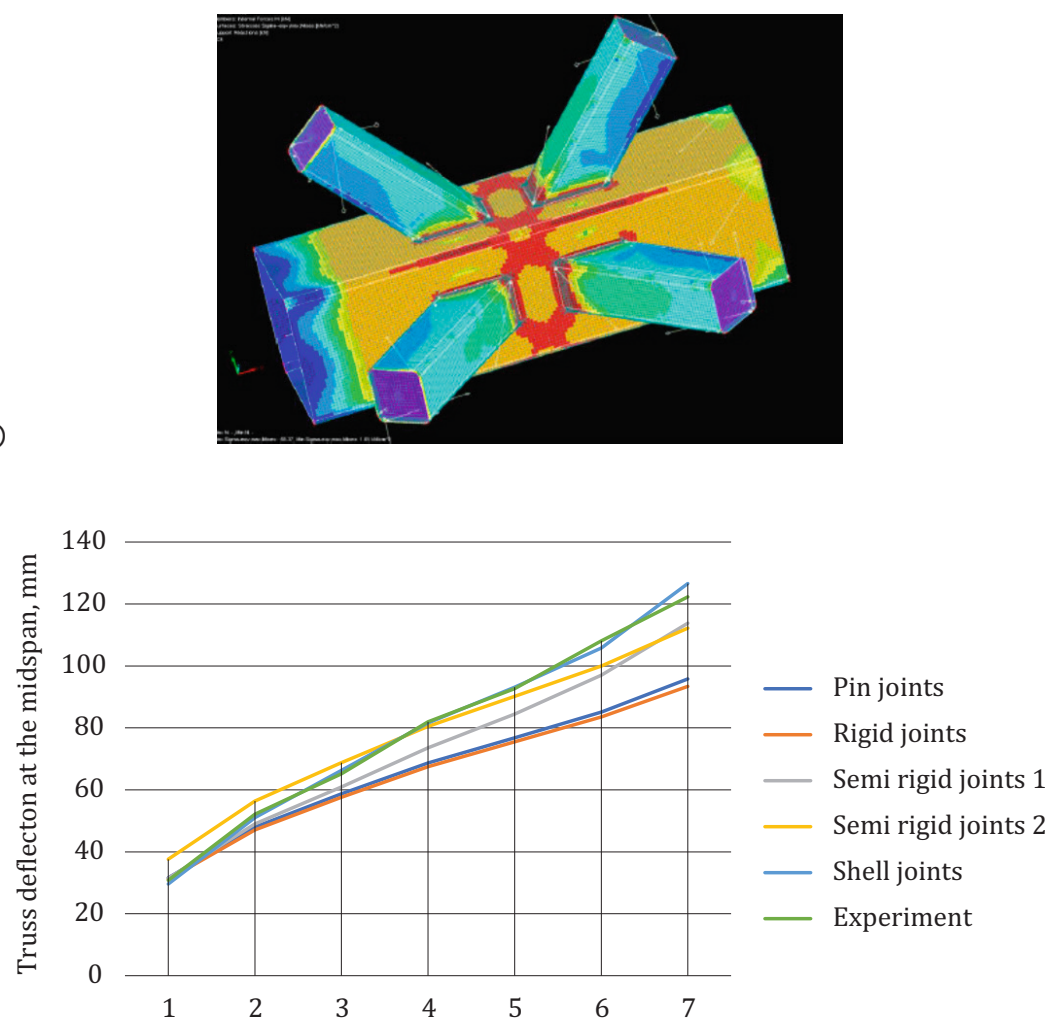

b)

Loading scheme
Andrejs Podkoritovs, Dmitrijs Serdjuks, Vadims Goremikins, Karina Buka-Vaivade, Mikhail Nikolaevich Kirsanov

Behaviour of a Space Inverted Triangular Steel Truss

Figure 13. a) Stresses first from the support joint of the bracings and bottom chord of the truss, determined using the fifth FEM model; b) comparison of the maximum vertical displacements obtained using five FEM models and experimentally (Podkoritovs, 2018) 
for the first and second models and for Loading scheme 4 exceeded $10 \%$ and $1.8 \%$ for the third and fourth models, correspondingly. Therefore, it can be concluded that the third and fourth FEM models of the inverted triangular truss allow predicting correctly the behaviour of the truss in case its members and joints are in the plastic stage.

However, the best correlation between the maximum vertical displacements obtained experimentally and analytically was obtained in the fifth model and did not exceed 3.9\%. The deformed scheme of the inverted triangular truss obtained using software Dlubal RFEM is shown in Figure 12.

Nevertheless, it should be mentioned that modelling of the joints by the shell type finite elements seriously increases the time necessary for the analysis of the truss of the fifth FEM model. However, the fifth FEM model enables to predict behaviour of the joints of the truss when it is in the plastic stage. The development of the stresses first from the support joint of the bracings and bottom chord are shown in Figure 13a for Loading scheme 4 , when plastic behaviour of the joint material started. The comparison of the maximum vertical displacements obtained using five FEM models and experimentally are shown in Figure 13b.

The obtained results let us conclude that the fifth FEM model can be considered preferable for prediction of the inverted hollow section triangular truss behaviour.

\section{Conclusions}

Behaviour of the inverted triangular truss with hollow sections was analysed analytically and experimentally. The truss with the length of $12.56 \mathrm{~m}$ made of steel grade $\mathrm{S355} 2 \mathrm{~J}$ with the depth and width of $800 \mathrm{~m}$ and $1480 \mathrm{~mm}$, correspondingly, was considered as the object of investigation.

It was shown that the FEM model of the truss where the members were modelled by the truss type finite elements but the joints - by the shell type ones allows predicting the behaviour of the truss with precision of up to $3.9 \%$ in the elastic and plastic stages of material behaviour of joints and members.

It was demonstrated that the precision of the suggested FEM model grows 4.36-4.62 times in comparison with the traditional FEM models where the members were modelled by the truss finite elements with the pinned and rigid bracing and chord joints in case when the joint material behaves plastically. The precision of the suggested FEM model is identical to the traditional FEM models in case the joints behave elastically. 


\section{Acknowledgements}

The authors' team would like to express sincere gratitude to Dr. sc. ing. Andrejs Kovalovs for his help in the development of the FEM models of the inverted triangular truss.

\section{Funding}

The inverted triangular truss, so as equipment and devices for its experimental testing were provided by the structural company UPB.

\section{REFERENCES}

Belevičius, R., Juozapaitis, A., Rusakevičius, D., Misiūnaitè, I., \& Valentinavičius, S. (2017). Optimal schemes of underslung girder foot bridges for different spans and deck types. Bauingenieur, 92(October), 427-434.

Blandford, G. E. (1996). Progressive failure analysis of inelastic space truss structures. Computer Structure, 58(4), 981-990. https://doi.org/10.1016/0045-7949(95)00217-5

Coutie, M. G., \& Saidani, M. (1991). Comparison of the theoretical behaviour of two rectangular hollow section trusses. In the Proceedings of the 4th International Symposium on Tubular Structures (pp. 334-343). The Netherlands, Delft.

Czechowski, A., Gasparski, T., Zycinski, J., \& Brodka, J. (1984). Investigation into the static behaviour and strength of lattice girders made of RHS. Document No. XV-E-052-84, International Institute of Welding, Paris, France.

Dauner, H. G., Oribasi, A., \& Wery, D. (1998). The Lully viaduct, a composite bridge with steel tube truss. Journal of Constructional Steel Research, 46(1-3), 67-68. https://doi.org/10.1016/s0143-974x(98)00025-x

Durfee, R. H. (1986). Review of triangular cross section truss systems. Journal of Structural Engineering, 112(5), 1088-1096. https://doi.org/10.1061/(ASCE)0733-9445(1986)112:5(1088)

Durfee, R. H. (1987). Design of a triangular cross section bridge truss. Journal of Structural Engineering, 113(5), 2399-2414. https://doi.org/10.1061/(ASCE)0733-9445(1987)113:12(2399)

European Committee for Standardization. (2005). EN 1993-1-1:2005: Eurocode 3: Design of steel structures - Part 1-1: General rules and rules for buildings.

Frater, G. S., \& Packer, J. A. (1992). Modelling of hollow structural section trusses. Canadian Journal of Civil Engineering, 19(6), 947-959. https://doi.org/10.1139/192-113

Gao, L., Bai, L., Jiang, K., Wang, Q., \& He, X. (2018). The Stability of a Movable High-Strength Inverted Triangular Steel Bridge. Mathematical Problems in Engineering, 2018, 1-12. https://doi.org/10.1155/2018/1568629
Andrejs Podkoritovs, 
Gusevs, J., Serdjuks, D., Artebjakina, G. I., Afanasjeva, E. A., \& Goremikins, V. (2016). Behaviour of load-carrying members of velodromes' long-span steel roof. Magazine of Civil Engineering, 65(5), 3-16. https://doi.org/10.5862/mce.65.1

Kirsanov, M. N., \& Zaborskaya, N. (2017). Deformations of the periodic truss with diagonal lattice. Magazine of Civil Engineering, 71(3), 61-67.

Liu, X. Y., \& Li. L. (2013). An analysis on structure type selection and optimization of the formtraveller for cantilever construction. Applied Mechanics and Materials, 454, 140-144.

https://doi.org/10.4028/www.scientific.net/amm.454.140

Misiūnaitè, I., Rimkus, A., Jakuboskis, R., Sokolov, A., \& Gribniak, V. (2019). Analysis of local deformation effects in cold-formed tubular profiles subjected to bending. Journal of Constructional Steel Research, 160, 598-612. https://doi.org/10.1016/j.jcsr.2019.06.006

Mohamad, A. A., Isaev, S. A., \& Vatin, N. I. (2016). Development of Modified formulae for detection the welding stresses in the welded steel cross-sections. Materials Physics and Mechanics, 26(1), 9-15.

Packer, J. A., Wardenier, J., Zhao, Z. L., Vegte, G. J., \& Kurobane, Y. (2009). Design Guide for rectangular hollow section (RHS) joints under predominantly static loading (2nd ed.). Kolns: CIDECT, Verlag TUV Rheinland GmbH, 154 p.

Paeglite, I., Smirnovs, I., \& Paeglitis, A. (2018). Evaluation of the increased dynamic effect on the highway bridge superstructure. Baltic Journal of Road and Bridge Engineering, 13(3), 301-312. https://doi.org/10.7250/bjrbe.2018-13.418

Philiastides, A. (1988). Fully overlapped rolled hollow section welded joints in trusses (Ph.D. thesis, Department of Civil Engineering, University of Nottingham, Nottingham, United Kingdom).

Podkoritovs, A. (2018). Behavior's Analyze for Space Triangle Steel Truss (M.S. Thesis, Riga Technical University, Riga, Latvia).

Reis, A., \& Oliveira Pedro, J. J. (2011). Composite Truss Bridges: new trends, design and research. Steel Construction, 4(3), 176-182, https://doi.org/10.1002/stco.201110024

Zhang, D., Zhao, Q., Li, F., \& Huang, Y. (2017). Experimental and numerical study of the torsional response of a modular hybrid FRP-aluminum triangular deck-truss beam. Engineering Structures, 133, 172-185.

https://doi.org/10.1016/j.engstruct.2016.12.007 